\title{
Charlotte Brody Discovery Garden
}

\section{Methods Document for Landscape Performance Benefits}

Research Fellow: Andrew Fox, PLA, ASLA, Associate Professor/University Faculty Scholar, North Carolina State University

Research Assistant: Sadie Walters, Student ASLA, MLA Candidate, North Carolina State University

Research Volunteer: Pei Chi (Peggy) Huang, MLA Candidate, North Carolina State University

Firm Liaison: Jesse Turner, PLA, MLA, Lift Environmental Design (formerly Jesse Turner Landscape Architect)

Overview of CSI: This investigation was conducted as part of the Landscape Architecture Foundation's 2015 Case Study Investigation (CSI) program. CSI matches faculty-student research teams with design practitioners to document the benefits of exemplary high-performing landscape projects. Teams develop methods to quantify environmental, economic and social benefits and produce Case Study Briefs for LAF's Landscape Performance Series.

\section{Landscape Performance Benefits \& Methodologies}

\section{Environmental Performance Benefits}

1. Reduces annual runoff by $80 \%$ or 915,246 gallons, the equivalent of 1.4 Olympicsize pools.

\section{Method:}

Stormwater management of the site was designed to manage runoff from a 1-inch storm event. The site, a total of $42,202 \mathrm{ft}^{2}$, consists of $32,473 \mathrm{ft}^{2}$ permeable surfaces and $9,729 \mathrm{ft}^{2}$ impermeable surfaces. The water management systems consist of a bioretention cell (i.e., rain garden) and two cisterns with a combined holding capacity of 5,000 gallons. According to calculations using the US EPA National Stormwater Calculator. $80 \%$ of on-site runoff is captured and treated by the stormwater best management practices (BMPs). This is consistent with the $80 \%$ reduction estimated by the project engineer during design and permitting.

\section{Data:}

All stormwater calculations were modeled using the US EPA National Stormwater Calculator using the following known values:

Total developed area $=42,024 \mathrm{ft}^{2}$

Total area treated by BMPs $=42,024 \mathrm{ft}^{2}$

Average annual rainfall in Durham, $\mathrm{NC}=49.4$ "

Runoff Reduction Totals:

Pre-development Average Annual Runoff = 43.6" 
Post-development Average Annual Runoff $=8.8$ "

$43.6 "-8.8 "=34.8 " ; 34.8 " / 43.6 "=.798(\sim 80 \%$ reduction $)$

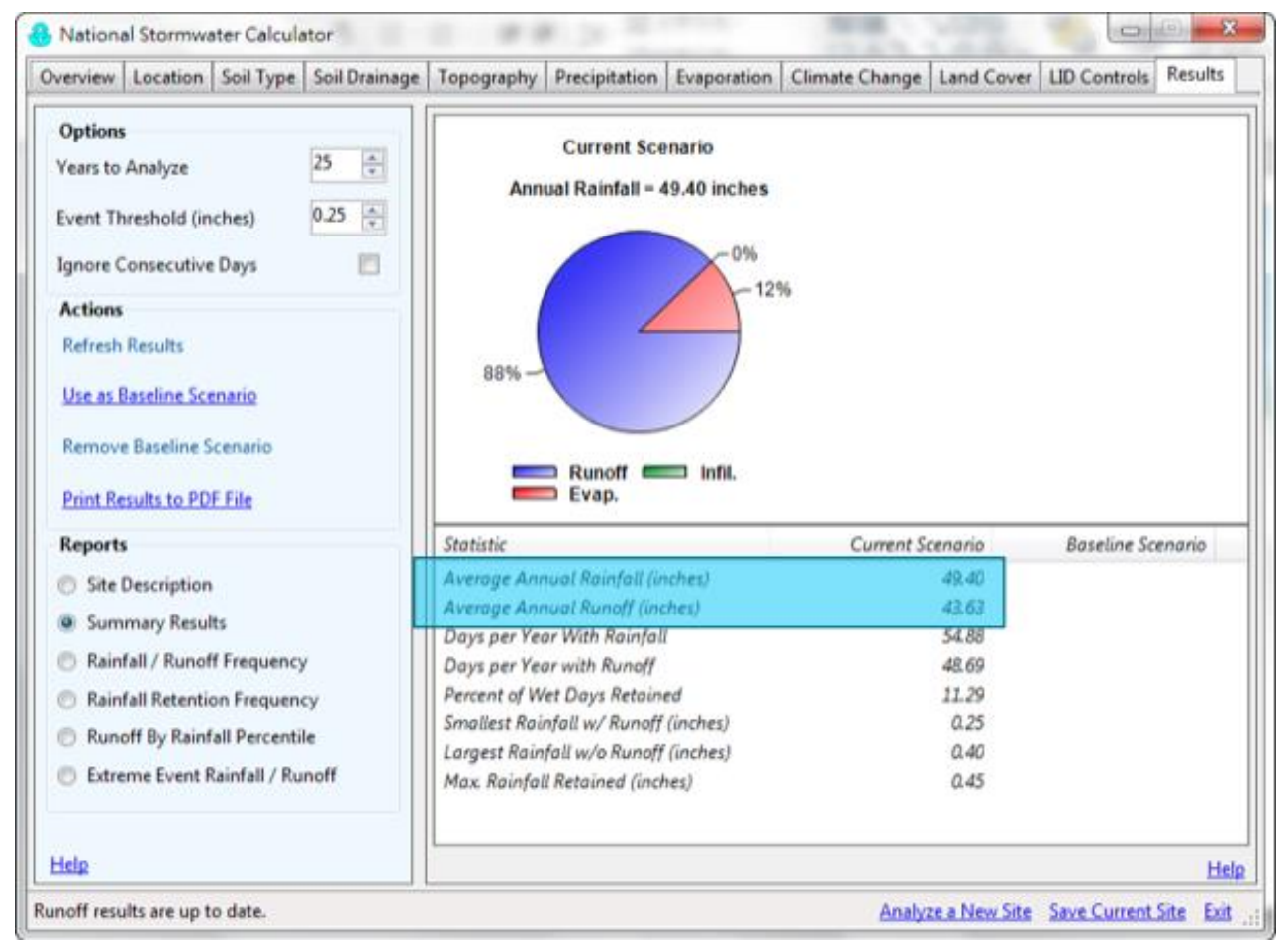

Figure 1: Pre-development (baseline) runoff model

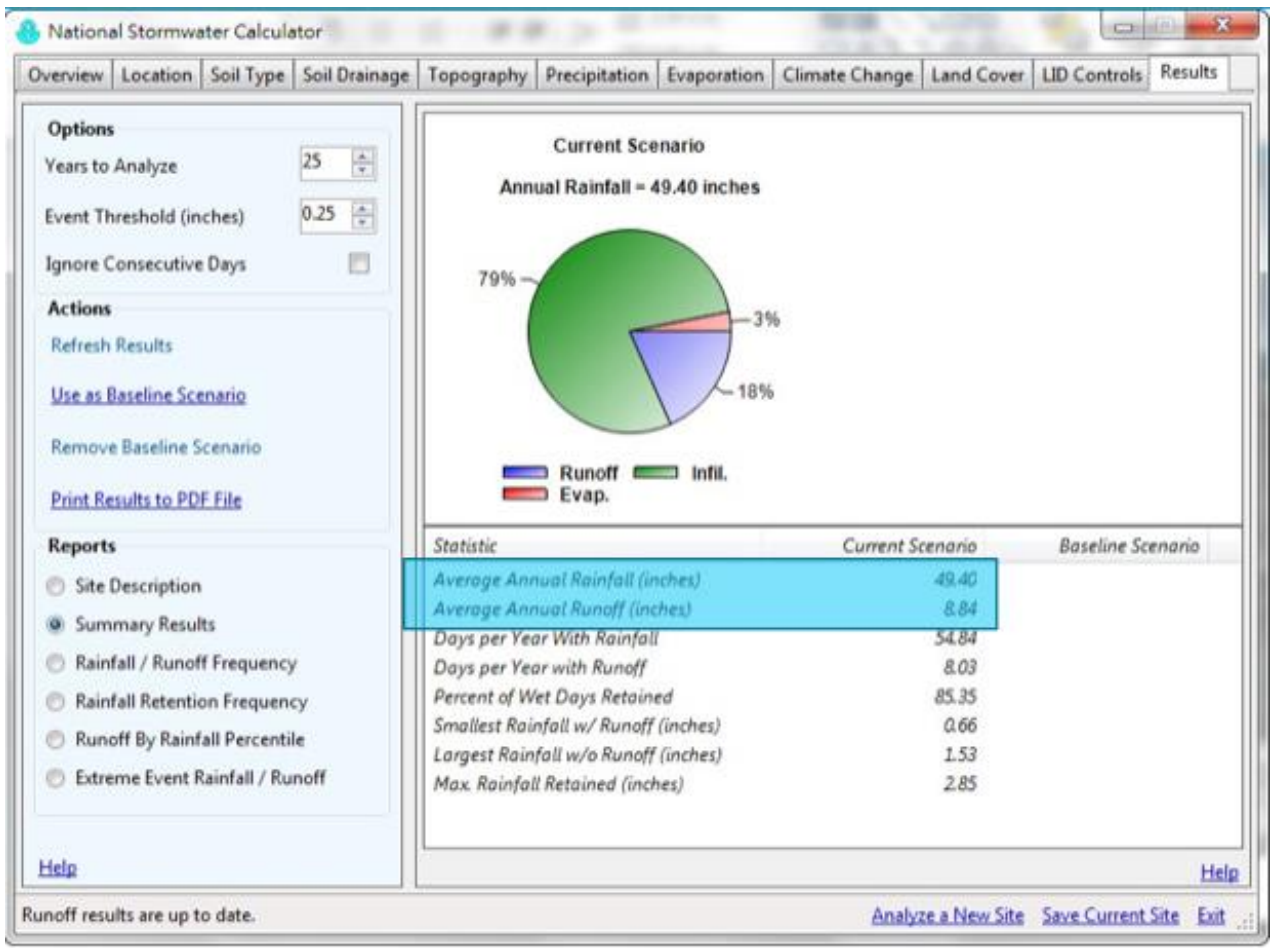

Figure 2: Post-development runoff model 
Treatment Volume Conversion:

Total cistern capacity $=5,000$ gal

Annual Average Runoff Difference: 34.8”

Runoff Volume $=$ Runoff depth $*$ drainage area

Reduction Volume $=34.8 ” * 42,202 \mathrm{sf}=122,350.6$ cubic ft., or $\sim 915,246$ gal.

Pool Equivalency Conversion:

Olympic size pools measure 50 meters long, 25 meters wide, and a minimum of 2 meters deep (USA Swimming, 2015).

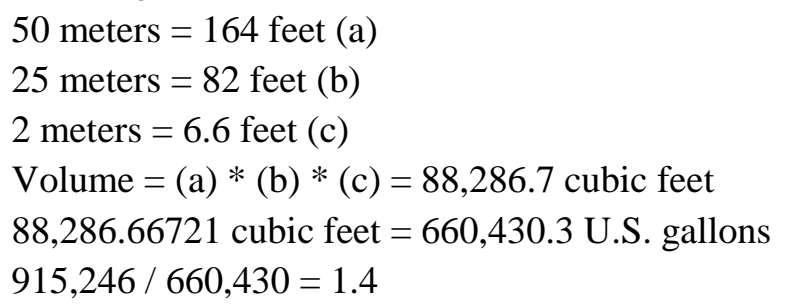

\section{Limitations:}

Calculations assume that the cisterns are completely emptied during intermittent dry periods and, therefore, are capable of capturing their full capacity of 5,000 gallons during all rain events.

Actual storm event collection data was not available; therefore all calculations and resulting conclusions were made using the US EPA National Stormwater Calculator.

\section{References:}

Charlotte Brody Discovery Garden Sustainable Sites Initiative: Construction scorecard. (2011). Lady Bird Johnson Wildflower Center of the University of Texas at Austin, the U.S. Botanic Garden, and the American Society of Landscape Architects.

USA Swimming. (2015). Available online: http://www.usaswimming.org/ Rainbow/Documents/d88245f7-325a-464b-84c67db3891422fc/Pool\%20Dimensions\%20and\%20Reccomendations.pdf

US EPA. 2015. National Stormwater Calculator, available online: http://www2.epa.gov/waterresearch/national-stormwater-calculator

2. Saved at least 25,952,000 BTUs in embodied energy by using recycled materials. This is the energy equivalent of driving 7,414 miles in a 35 mile-pergallon passenger vehicle.

\section{Method:}

Embodied energy is an important calculation for landscape architects to make as it can be used to compare the environmental impacts different materials and, in this case, the environmental impacts avoided by using recycled materials. As described by Meg Calkins, "embodied energy refers to the total energy consumed in raw material acquisition, manufacture, transport, use and disposal of building material/product" (p.337). The standard unit of calculation for embodied energy is the British Thermal Unit, or BTU. One (1) BTU is the amount of energy needed to raise the temperature of one (1) pound of water one (1) degree Fahrenheit. 
The BTU data and standard conversion equations were sourced from Sustainable Landscape Construction (Thompson and Sorvig, 2007). BTU equivalents, i.e., BTUs per mile of vehicular travel, were also taken from Thompson and Sorvig (p.278). All calculations and conversions are provided below.

\section{Data:}

Recycled Brick $=1,075 \mathrm{BTU} / \mathrm{lb}$. (with a range up to 4,085 BTU/lb.)

10.6 tons (per Mottern, 2015) used on site $(10.6$ x 2,000 = 21,200 lbs.)

$22,790,000 \mathrm{BTU}$ (with a range up to $86,602,000 \mathrm{BTU}$ )

35-MPG vehicle consumes 3,500 BTU/mi.

- 22,790,000 BTU $\div 3,500 \mathrm{BTU}=6,511 \mathrm{mi}$. (total BTU value of brick used $\div$ $\mathrm{BTU} / \mathrm{mi}$. for a $35 \mathrm{MPG}$ vehicle $=$ total miles of travel)

- $6,511 \div 2,840=2.29$

The use of 10.6 tons of brick is equivalent to driving a 35-MPG car 6,511 miles or 2.29 round trips from the NC State Campus in Raleigh, North Carolina to the Golden Gate Bridge in San Francisco, California.

Recycled Lumber $=1,054 \mathrm{BTU} / \mathrm{lb}$.

1.5 tons (per Mottern, 2015) used on site $(1.5$ x 2,000 = 3,000 lbs.)

$3,162,000 \mathrm{BTU}$

35-MPG vehicle consumes 3,500 BTU/mi.

- 3,162,000 BTU $\div 3,500 \mathrm{BTU}=903 \mathrm{mi}$. (total BTU value of brick used $\div \mathrm{BTU} / \mathrm{mi}$. for a $35 \mathrm{MPG}$ vehicle $=$ total miles of travel)

- $903 \div 280=3.23$ (total miles $\div$ distance between Raleigh, NC and Washington, $\mathrm{DC}=$ number of trips)

The use of 1.5 tons of lumber is equivalent to driving a 35-MPG car 903 miles or 3.23 round trips from Raleigh, North Carolina to Washington, DC

Mileage Equivalency Conversion:

- 22,790,000 BTU + 3,162,000 BTU = 25,952,000 BTU (brick BTU + lumber $\mathrm{BTU}=$ total BTU)

- 25,952,000 BTU $\div 3,500 \mathrm{BTU} / \mathrm{mi}$. = 7,414 $\mathrm{mi}$. (total BTU $\div \mathrm{BTU} / \mathrm{mi}$. for a 35 MPG vehicle $=$ total miles of travel)

- $7,414 \div 2,840=2.61$ (total miles $\div$ distance between Raleigh, NC and San Francisco, $\mathrm{CA}=$ number of trips)

\section{Limitations:}

BTU values found in Sustainable Landscape Construction (Thompson and Sorvig, 2007) were used for all embodied energy calculations. While some wood had one recorded BTU value, brick was given a wide range of values, 1,075 - 4,085 BTU/lb., which then translates into an extremely broad range when converted into mileage, 6,511 - 24,743 miles. Because of the uncertainty of where the CBDG brick materials would be valued within this broad spectrum, and due to the close proximity of brick manufacturing and abundance of both raw and processed brick materials 
within the North Carolina Piedmont region, the authors chose to use the most conservative values to report the minimum calculated benefit, and therefore avoid overstating performance.

\section{References:}

Calkins, M. (2009). Materials for sustainable sites: a complete guide to the evaluation, selection, and use of sustainable construction materials. Hoboken, NJ: Wiley.

Thompson, J. William, and Sorvig, Kim. (2007). Sustainable Landscape Construction: A Guide to Green Building Outdoors (2nd Edition). Washington, DC, USA: Island Press.

Correspondence with Robert Mottern III, Head of Horticulture, Sarah P. Duke Gardens on May $27,2015$.

3. Reduces afternoon summer surface temperatures under the pergola and work area shade structures by an average of $33^{\circ} \mathrm{F}$ compared to the paths in full sun.

\section{Method:}

Temperatures taken under shaded areas at scheduled intervals of the day and compared with temperatures taken from non-shaded areas in the garden using the same method. Temperature readings were taken using the 165 Flir IR thermometer (accuracy of $+/-1.5 \mathrm{C}$ ).

\section{Data:}

Temperature data was gathered on June 30, 2015 between 6:30 and 7:00am and again between $2: 30$ and $3: 00 \mathrm{pm}$. Based on weather data taken from a station less than two miles from the site, the morning temperature was $67^{\circ} \mathrm{F}$ with $78 \%$ humidity and the afternoon temperature was $88^{\circ} \mathrm{F}$ with $48 \%$ humidity. There were scattered clouds throughout the day, however all readings were taken when no cloud cover was present.

Calculation:

Temperature difference from sunny area - (Average temperature difference from various shaded areas $)=$ temperature reduction provided by shade structures:

$$
\begin{aligned}
& 83+81 / 2=82 \\
& 115-82=33
\end{aligned}
$$

\section{Limitations:}

Obtaining a 24-hour average over a series of days, including various weather conditions, would give a more accurate sense of the overall effectiveness of the shade structures. Four outdoor temperature-recording kits would be the type of equipment used to obtain this average, and the cost makes the use of this equipment unfeasible. 


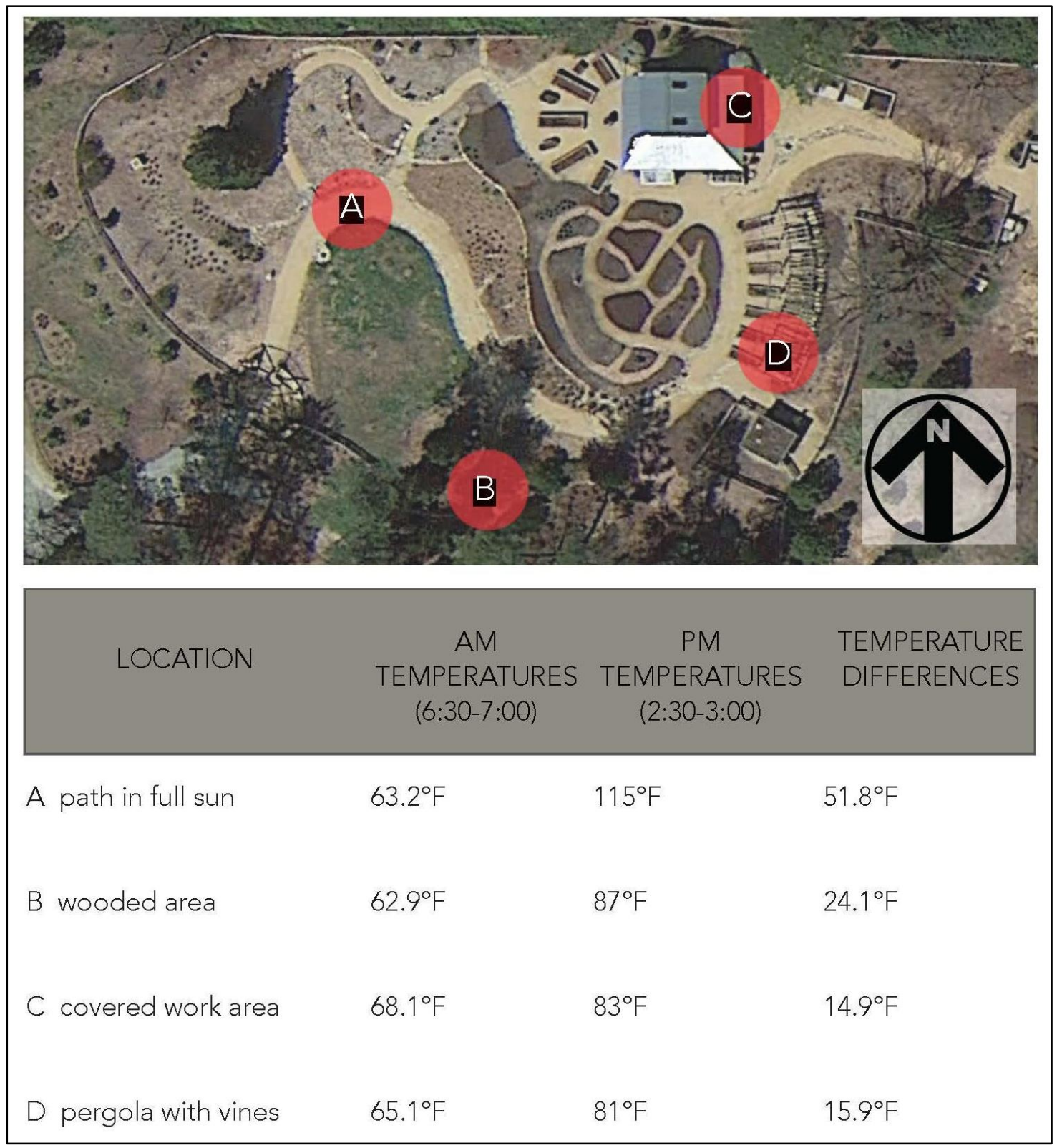

Figure 3: Temperature recording locations, conditions, and results

\section{References:}

NA

\section{Social Performance Benefits}

1. Introduced 9,848 individuals to environmental issues and methods of sustainable land stewardship in 2014 by delivering more than 548 educational sessions to 8,578 participants and hosting 1,270 attendees at other garden festivities.

Method: Numbers obtained from 2014 attendance records of educational programs on the site. 


\section{Data:}

In 2014, staff at Duke Gardens recorded the following (per Little, 2015):

Total number of garden festivity attendants $=1,270$

Total number of program attendants $=8,578$ :

- 15 adult programs with 171 participants

- 5 family programs with 220 participants

- 11 youth classes with 141 participants, and

- 537 grade school programs with 8,046 participants.

Total: $8,578+1,270=9,848$ attendants

\begin{tabular}{|c|c|c|c|c|c|}
\hline $\begin{array}{c}\text { Garden } \\
\text { Layout }\end{array}$ & $\begin{array}{l}\text { Vegetable } \\
\text { Production }\end{array}$ & Soil Health & $\begin{array}{c}\text { Ecological } \\
\text { Systems }\end{array}$ & $\begin{array}{c}\text { Garden } \\
\text { Festivities }\end{array}$ & $\begin{array}{c}\text { Grade } \\
\text { School } \\
\text { Programs }\end{array}$ \\
\hline 50 & 264 & 50 & 168 & 1,270 & 8,046 \\
\hline
\end{tabular}

Figure 4: Garden program topics with respective attendants

\section{References:}

Correspondence with Jan Little, Education and Public Programs Director, Sarah P. Duke Gardens on June 7 and July 2, 2015.

2. Produced and donated $1,648 \mathrm{lbs}$. of organic vegetables, valued at $\$ 6,030$, to local food banks in 2014.

\section{Method:}

The Vegetable Calculator is a value calculator generated by PlanGarden.com, which uses national pricing averages to value each vegetable based on weight of harvest. All of the garden's handwritten harvest notes included date of harvest, vegetable and weight of harvest. The garden notes were compiled and transferred to the value calculator to glean value of all vegetables that were harvested and donated to charitable organizations. Because the Charlotte Brody Discovery Garden is an organic garden, all produce is valued higher than grocery and farmer's market values. 


\section{Data:}

\begin{tabular}{|c|c|c|c|c|c|}
\hline $\begin{array}{c}\text { Vegetable } \\
\text { or Herb }\end{array}$ & $\begin{array}{c}\text { Space Used } \\
\mathrm{ft}^{2}\end{array}$ & $\begin{array}{c}\text { Veg } \\
\text { lb/ft }\end{array}$ & $\begin{array}{c}\text { Vegetable } \\
\text { Price/lb }\end{array}$ & $\begin{array}{c}\text { Veg } \\
\text { Grown } \\
\text { Ib }\end{array}$ & Total \\
\hline Squash, Summer, Yellow $\hat{v}$ & 6 & 0.9 & 2 & 111.75 & 223.50 \\
\hline Squash, Summer, Zucchini $\hat{v}$ & 4 & 0.9 & 2 & 15.25 & 30.50 \\
\hline Squash, Winter, Butternut $\hat{v}$ & 4 & 0.6 & 2 & 21 & 42.00 \\
\hline Garlic & 3 & 0.2 & 8 & 5.25 & 42.00 \\
\hline Onion, Bulb & 1.69 & 2.3 & 2.55 & 50 & 127.50 \\
\hline Okra & 9 & 6.2 & 1 & 194 & 194.00 \\
\hline Pepper, Jalapeño & 2 & 0.6 & 3 & 163 & 489.00 \\
\hline Pepper, Bell & 6 & 0.9 & 5 & 151.25 & 756.25 \\
\hline Tomato, Large & 3 & 2.6 & 2.67 & 83.75 & 223.61 \\
\hline Tomato, Cherry & 2 & 2 & 4 & 249 & 996.00 \\
\hline Eggplant & 2 & 0.9 & 2.5 & 79.25 & 198.13 \\
\hline Peas, English & 3 & 0.5 & 3 & 9.5 & 28.50 \\
\hline Bean, Bush & 10 & 0.8 & 2.5 & 33 & 82.50 \\
\hline Watermelon & 6 & 6.6 & 2 & 191.25 & 382.50 \\
\hline Potato & 2 & 0.9 & 5 & 180.5 & 902.50 \\
\hline Corn & 10 & 1 & 0.66 & 60 & 39.60 \\
\hline Radish, Red & 9 & 6.2 & 1 & 16.5 & 16.50 \\
\hline Cucumber & 8 & 3.2 & 1.49 & 33.5 & 49.91 \\
\hline Add Vegetable & \multicolumn{5}{|l|}{ Recalculate } \\
\hline Grocery $\bigcirc$ Farmers Mar & ket Orga & & $\begin{array}{l}\text { Grand } \\
\text { Totals }\end{array}$ & 1647.75 & 6030.63 \\
\hline
\end{tabular}

Figure 5: Recorded produce donations and Vegetable Calculator valuations

\section{Limitations:}

The Vegetable Calculator does not account for the increased value of heirloom vegetables, nor does it distinguish between some types of produce. For example, the calculator includes watermelon, but not honeydew melon. Lastly, records kept by the garden were not consistent. Some records showed weights of singular produce types as well as the number of fruits harvested whereas other records showed numbers of fruit harvested and the weights of an entire harvest, including a variety of vegetables (per Mottern, 2015). The latter method of record keeping required weight estimates to be made based on number of fruits. 


\section{References:}

Correspondence with Robert Mottern III, Head of Horticulture, Sarah P. Duke Gardens on May 27, July $2 \& 7,2015$.

PlanGarden. (2015). Vegetable Calculator. Available online: http://www.plangarden.com/app/vegetable_value/

\section{Economic Performance Benefits}

1. Provides annual training and volunteer opportunities for 15-20 participants, who from 2012-2014 contributed over 1,912 hours, which is valued at \$41,050.

Method: According to Independent Sector, a coalition of charities, foundations, corporations, and individuals that publishes research important to the nonprofit sector, monetizing the value of volunteer time is a generally accepted way of valuing volunteer time. As indexed from the U.S. Bureau of Labor Statistics data, the 2014 rate in the State of North Carolina was \$21.47, based on an average of hourly earnings of all production and non-supervisory workers on private, non-farm payrolls, plus 12\% (Independent Sector, 2015).

\section{Data:}

Volunteer hours (per Mottern, 2015):

$$
\begin{aligned}
& \text { Prior to } 2011=0 \\
& 2012=545 \\
& 2013=794 \\
& 2014=573
\end{aligned}
$$

Totals:

$$
\begin{aligned}
& 545+794+573=1,912 \\
& 1,912 * 21.47=41,050.64
\end{aligned}
$$

\section{Limitations:}

Because regular volunteer records are not kept, hours are based on an average of 13 to 15 volunteers.

\section{References:}

Correspondence with Robert Mottern III, Head of Horticulture, Sarah P. Duke Gardens on May 21 and June 7, 2015.

Independent Sector. (2015). Available online: http://www.independentsector.org/volunteer_time

\section{Cost Comparison:}

Duke Gardens demands excellence and holds its designers and contractors to high standards. While a $\$ 950,000$ garden that demonstrates organic gardening practices may seem like a high price tag, this budget represents a 52.5\% cost savings as compared with pricing for special "destination" gardens as it is common for destination children's gardens to cost, on average, \$2 million per acre (Terra Design Studios, 2015). The high cost of most destination gardens is 
primarily due to the cost of intense play features with complicated system components, such as water play or thematic hardscapes (Terra Design Studios, 2015).

At the Charlotte Brody Discovery Garden, the design team took a decidedly different approach. The goal was to create an elegant and simple garden that invites users to appreciate the natural world. The Discovery Garden provides culturally relevant, and often unique, fruits and vegetables (i.e., giant okra plants) which engage children in the process of learning about and appreciating where food comes from. The most essential investment in the Discovery Garden is the craft and focus in each simple element.

\section{References:}

Terra Design Studios. (2015). Construction Cost Summary for Children's Gardens in Public Gardens. 